\title{
TRANSLATOR'S FOREWORD
}

\author{
RUARI MCLEAN
}

Jan Tschichold's first book. Die neue Typographie, was published in Berlin in 1928. Its design was not only startling. with its famous frontispiece of solid black facing the title, but also extremely elegant, in a soft black linen case blocked in silver. This was six years after D. B. Updike's Printing Types was published in the United States, two years before Stanley Morison's article "First Principles of Typography" appeared in The Fleuron 7, and three years before Eric Gill's Essay on Typography. It was out of print by 1931 and remained out of print for fifty-six years, until the Brinkmann \& Bose facsimile reprint of 1987.

Tschichold was recognized by a few people in Britain and the USA before 1939. A small exhibition of his work was held in the London office of a forward-looking printer. Percy Lund Humphries, between 27 November and 14 December 1935 (probably at the suggestion of Edward McKnight Kauffer); an article on his work by Robert Harling appeared in Printing in January 1936: and in 1937 Tschichold himself read a paper "A New Approach to Typography" to the Double Crown Club in London. The design of the menu for that dinner showed how little Tschichold's ideas, and those of the modern movement generally, were understood in Britain at that time. $\mathrm{He}$ continued to be supported by Lund Humphries, for whom he designed the firm's letterhead, in use from 1936 to 1948 , and the 1938 edition of the Penrose Annual.

In March 1947 Tschichold came to England to overhaul the typography of the fast-growing paperback publisher Penguin Books (founded in 1935)where he stayed for three years. But it was not until 1967 that any book of his appeared in English translation. This was his sixth book, Typographische Gestaltung, originally published in Basel in 1935 and now appearing under the title of Asymmetric Typography. It had been translated by the present writer in 1945, but remained without a publisher until Cooper \& Beatty, the Toronto typesetters, sponsored it for distribution in the USA by Reinhold and in Britain by Faber \& Faber.

In the same year, 1967. Tschichold asked me to translate Die neue Typographie. He planned it as a second, revised edition. He gave me a copy of the text with numerous corrections, editorial revisions, and deletions of matter he considered to be no longer relevant or now out of date: for example the entire section on standardization was taken out. It should be remembered that in a speech made to the Type Directors Club of New York in 1959 (later printed in Print under the title "Quousque Tandem . . ."). he 
said: "What I do today is not in the line of my often mentioned book Die neue Typographie, since I am the most severe critic of the young Tschichold of 1925-8. A Chinese proverb says 'In haste there is error.' So many things in that primer are erroneous, because my experience was too smali."

I translated the greater part of Die neue Typographie incorporating all the revisions, but again no publisher could be found. When Tschichold died in 1974. I placed the draft of my translation in the St Bride Printing Library in London where it could be consulted by anyone who wished to read it.

Now the University of California Press has enabled the book to appear at last in English, but in a new translation made exactly from the original text. It is therefore treated as a text of historical importance rather than the latest publication of Tschichold's thoughts.

All the self-critical comments written by Tschichold on his revised proofs are printed below, and two of his original pages are reproduced. The original passages of text were to stand unaltered. It was not feasible to show here the cuts and other corrections, which although numerous were not of serious textual importance. In the second edition which Tschichold had planned, there would certainly have been typographical changes: paragraphs were to be indented, and book and magazine titles italicized, in accordance with modern practice. Indented paragraphs have not been introduced in the present translation, and the illustrations, some of which Tschichold intended to change or omit, are unaltered.

Tschichold's text was epoch-making when first published. Its fundamental tenets are still absolutely valid: the book is as well worth reading today as it ever was.

For helping me at various times with my translation I must express my gratitude first to the late Hans Unger, and later to Hans Dieter Reichert, Jost Hochuli, Robin Kinross, and my Californian copy editor Nicholas Goodhue. But any grievous errors must be my own. 